\title{
ASSESSMENT OF TRAFFIC NOISE POLLUTION DUE TO URBAN RESIDENTIAL ROAD TRANSPORT
}

Elena Lezhneva, $\mathrm{PhD}$, Associate professor, Kharkiv National Automobile and Highway University

Katerina Vakulenko, PhD, Associate professor, O. M. Beketov National University of Urban Economy in Kharkiv

Andrii Galkin, $\mathrm{PhD}$, Associate professor, O. M. Beketov National University of Urban Economy in Kharkiv

\section{Abstract}

The problem of combating urban noise is closely linked to the rational transformation of the urban environment, which must go through the elimination or reduction of the number of sources of noise, the localization of the noise emission zone, reducing the level of sound sources and protection against noise for the residential areas. Theoretical and experimental studies of acoustic loading on the territory along the highway for the typical section of the urban territory have been conducted. To estimate the complex noise impact from all sources and from individual sources, as well as to predict the total noise exposure for this site, a noise map was constructed using software. As a measure to combat traffic noise in the territory along the highway, the location of the noise protection screen was justified, taking into account the loss of part of the national income as a result of the continuous impact of noise on a person. The results of the research allow to assess the degree of technogenic impact of noise pollution during the operation of the highway, which allows regulating, by administrative and legislative methods, the nature of the impact on natural objects and human health of certain types of activities, as well as reasonably proposing measures that ensure environmental safety when organizing urban streets traffic.

Keywords: road transport, acoustic climate, traffic flows, traffic intensity, noise map, noise protection screen.

\section{INTRODUCTION}

Road transport is one of the main sources of environmental pollution. Along with the main part of the volume of harmful emissions into the atmosphere, the development of the road complex and, as a result, an increase in the traffic volume resulted in a real danger of changing the quality of the environment as a result of an abnormal change in sound characteristics (periodicity, force of sound) in settlements and other places. With the increase in the number of vehicles and the speed of their movement through the streets of industrial cities, the world community identified noise as one of the main factors 
ROMANIAN JOURNAL

OF TRANSPORT INFRASTRUCTURE

Elena Lezhneva, Katerina Vakulenko, Andrii Galkin

Assessment of traffic noise pollution due to urban residential road transport

that aggravate the living standards of people in cities. It is impossible to physically avoid noise pollution, it is possible only to subjectively ignore it. Emotional and physical stress associated with constant noise discomfort leads to noise stress. Therefore, the problem of noise pollution of the environment by transport highways is no less relevant than the chemical, as the studies determine the new aspects of the negative acoustic effect on the health of major cities residents. In the course of the study, an analysis of existing mathematical models was carried out to determine the expected noise level of the transport flow.

The constantly growing intensity of traffic flows annually is accompanied by increased man-made pressure on the population of modern cities. With the increase of automobilization level, speeds, etc.on the urban streets, the noise pollution is given primacy by world community. Noise pollution of the environment is an urgent problem for most EU countries.

The noise has an adverse effect on virtually all systems of the human body, causing both short-term and long-term and stable functional changes that lead to diseases of the cardiovascular, nervous and other systems, as well as the weakening of the immune system of the body [1]. Excessive noise can cause nervous exhaustion, mental depression, autonomic neurosis, peptic ulcer, endocrine and cardiovascular disorders. Noise interferes with people working and relaxing, reduces productivity and increases injuries at work and at home [2].

The negative influence of noise due to its physical parameters (sound pressure level, intensity, duration of exposure, constant or inconstant noise, etc.), the specifics of the human body (age, gender, health status, etc.) and the influence of the accompanying factors that can increase the harmful effects of noise. The impact of transport noise on a person can be considered in various aspects, in particular in relation to [3]:

- drivers;

- employees of administrative and office buildings, hospitals, schools and other facilities with special requirements regarding noise levels located near roads;

- residents of buildings located in close proximity to highways with significant traffic intensity.

The annual growth of the automobilization level has led to an increase noise pollution in large Ukrainian cities like Kiev (3 mil. people), Kharkiv (2 mil. people), Dnepr (1 mil. people), Odessa ( 1 mil. people), Lviv (0,8 mil. people), Zaporizhia ( 0,8 mil. people). The presence of high procentage of «old» vehicles in the traffic flow poses the problem of noise pollution and the 
ROMANIAN JOURNAL

OF TRANSPORT INFRASTRUCTURE

Elena Lezhneva, Katerina Vakulenko, Andrii Galkin

Assessment of traffic noise pollution due to urban residential road transport

impact on the residentson top. The installation of noise protection systems in Ukraine will be applied only on intercity routes and international highways, however, the need for their use at the main areas of the urban residences still needs research. Based on the leading experiencethe development of a complex system of noise protection is carried out in accordance with the necessary reduction of sound level, and the choice of screen structures is dictated primarily by considerations of the effectiveness of noise protection measures and their expenses, as well as security requirements, features of operation and aesthetic perception.

The article presents the research of acoustic climate in the residential area of the Kharkiv (Ukraine); an environmental protection measure to improve the environmental performance of transport infrastructure is proposed.

In the first stage, an analysis of existing mathematical models was performed to determine the expected noise level of the transport flow. After that,theoretical and experimental studies of acoustic loading at the urban residensial territory along the highway were carried out. A noise map was developed to estimate the noise exposure from all sources and the noise effect from individual sources, as well as to predict the total noise exposure for current residence via software «Acoustics 3D». As a measure to combat traffic noise in the territory along the highway, the location of the noise protection screen was justified, taking into consideration the loss of part of the national income as a result of the continuous impact of noise on a person. The research results allow to assess the degree of anthropogenic impact during the operation of the highway on the state of the environment by the example of the city roads of Kharkiv, which allows regulating, by administrative and legislative methods, the nature of the impact on natural objects and human health of certain types of activities, and also reasonably suggest safety in the organization of traffic on the streets of major cities.

\section{REFFERENCES REVIEW}

The need to combat noise in Ukraine is enshrined in law in accordance with the law of general action «On Environmental Protection». The noise penetrating a room or territory should not exceed the standard values established by building codes, standards and sanitary norms.

Sanitary norms of permissible noise necessitate the development of technical, architectural, planning and administrative measures aimed at creating a noise regime that meets the hygienic requirements, both in urban buildings and in various buildings that preserve the health and performance of the population. 
ROMANIAN JOURNAL

OF TRANSPORT INFRASTRUCTURE

Elena Lezhneva, Katerina Vakulenko, Andrii Galkin

Assessment of traffic noise pollution due to urban residential road transport

The main criteria for ensuring acoustic comfort in the residential building area are the normative equivalent noise levels of the residential area $-55 \mathrm{dBA}$ per day and $45 \mathrm{dBA}$ at night time [4].

The inhabitants of large cities are exposed to noise over a long period of time, so noise is especially dangerous for them. The total contribution of transport noise to the acoustic background of the residential area is estimated at $60-80 \%$. It has been established that transport noise affects residents of the residential area located near the highways, during 15-18 hours per day [5].

In conditions of road traffic on the urban streets, the noise level emitted by transport flows into the environment are influenced by factors such as the characteristics of the traffic flow and the characteristics of the environment (Fig. 1).

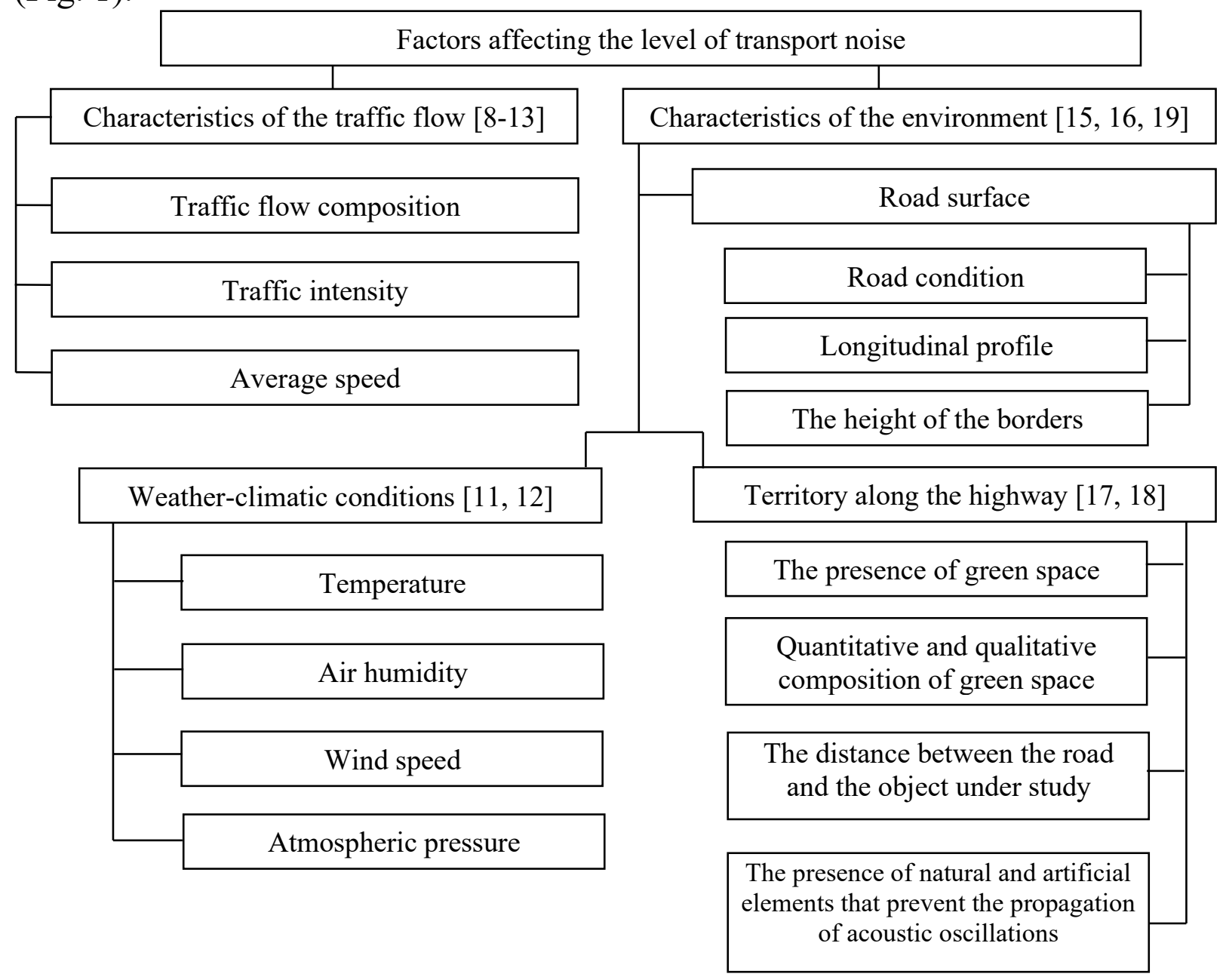

Figure 1. Factors affecting the level of transport noise [6] 
ROMANIAN JOURNAL

OF TRANSPORT INFRASTRUCTURE

Elena Lezhneva, Katerina Vakulenko, Andrii Galkin

Assessment of traffic noise pollution due to urban residential road transport

The traffic flow is a complex system of interaction between different types of vehicles with the road. Some researchers believe that the movement of vehicles in the flow may be presented as a determined and continuous process [7]. Others represent it as a stochastic process, since its characteristics allow prediction only with some degree of probability [8].

The problem of combating urban noise is closely linked to the rational transformation of the urban environment [9], which must go through the elimination or reduction of the number of sources of noise, the localization of the noise emission zone, reducing the level of sound sources and protection against noise for the residential areas.

At present, the huge practical experience of using various noise protection measures for reducing road transport noise is accumulated [10]. In Brazil [11], USA [12], Serbia [13], Italy [14], Canada [15], Romania [16], India [17] and other countries [18] tens of thousands of kilometers of acoustic screens are installed. Slovakia, France and Germany use a noise-absorbing road surface to reduce the noise of car tires [19]. Embankment and green plantations are successfully used to reduce the sound level in the way of its dissemination [12]. The development of a complex system of noise protection is carried out in accordance with the necessary reduction of sound level, and the choice of screen structures is dictated primarily by considerations of the effectiveness of noise protection measures and their cost [9], as well as security requirements, features of operation and aesthetic perception [2].

The problem of combating urban noise is closely linked to the rational transformation of the urban environment, which must go through the elimination or reduction of the number of sources of noise, the localization of the noise emission zone, reducing the level of sound sources and protection against noise of places of residences. The presented set of techniques for estimating the noise level in the off-road space has allowed us to develop an approach to justify the use of noise-protecting complexes at the urban residences.

\section{THE PURPOSE OF THE STUDY AND THE APPLIED METHODOLOGY}

The desire of researchers to make a predictive model for external noise of roads, as precise as possible, forces to consider a significant number of factors characterizing road conditions, external factors and parameters of the traffic flow, which make a different contribution to the overall noise emission process and bring differences to the final result, which ultimately worsens the predictive properties of the mathematical model. Dynamic noise mapping has beenstudied in [11], [14] and [21] previously. Those approaches present linear 
ROMANIAN JOURNAL

OF TRANSPORT INFRASTRUCTURE

Elena Lezhneva, Katerina Vakulenko, Andrii Galkin

Assessment of traffic noise pollution due to urban residential road transport

$2 \mathrm{~d}$ model with constant influence on each building on the street of the road network. According to the last research, constructions obtained different level of noise pollutions (fig. 1), therefore obtaining results for all buildings on the street and in the residential area are unique. Our approach present results of $3 \mathrm{~d}$ noise mapping for all residential zones, which is more efficienct to evaluate assessment of the bariers needs.An analysis of existing mathematical models [11-18] for determining the expected noise level $(L)$ of a traffic flow allows us to conclude that most of the forecasting models have the following form:

$$
L=A \pm B \lg N \pm C \lg V
$$

where $A, B, C$ - constants;

$N$ - vehicle traffic intensity, aut./hr;

$V$ - average speed of vehicles in the flow, $\mathrm{km} / \mathrm{hr}$.

Thus, by increasing the quantity of additional informative indicators in the prediction model, without taking into consideration the significance of their contribution to the overall noise emission process, it is possible to obtain results that will not be close to reality.

\section{THE RESULTS OF EXPERIMENTAL STUDIES}

For the estimation of noise pollution of the environment and rationale for the use of noise protection systems, a typical section of the urban area was selected in the Kharkiv residential area. The research was conducted in a neighborhood, which is located in the Slobodskii district of the Kharkiv city and is surrounded by the Molocna street, Derzhavinska street, Plekhanivska street and Haharinaavenue.The study was conducted in a sequence that is presented in Fig. 2.

At the first stage of the study, according to Fig. 2, road conditions were determined for each street, namely: the width of the roadbed and sidewalks, the presence or absence of lawns and trees, the nature of the building (small or multistory). The main territory within the microdistrict was studied (Table 1).

Within the local area an analysis of the intensity and composition of traffic flows in the winter and summer periods of 2018 is carried out, the environmental situation in the yards of the residential neighborhood is estimated. 
ROMANIAN JOURNAL

OF TRANSPORT INFRASTRUCTURE

Elena Lezhneva, Katerina Vakulenko, Andrii Galkin

Assessment of traffic noise pollution due to urban residential road transport

\section{STAGES OF INVESTIGATION OF NOISE POLLUTION BY ROAD TRANSPORT}

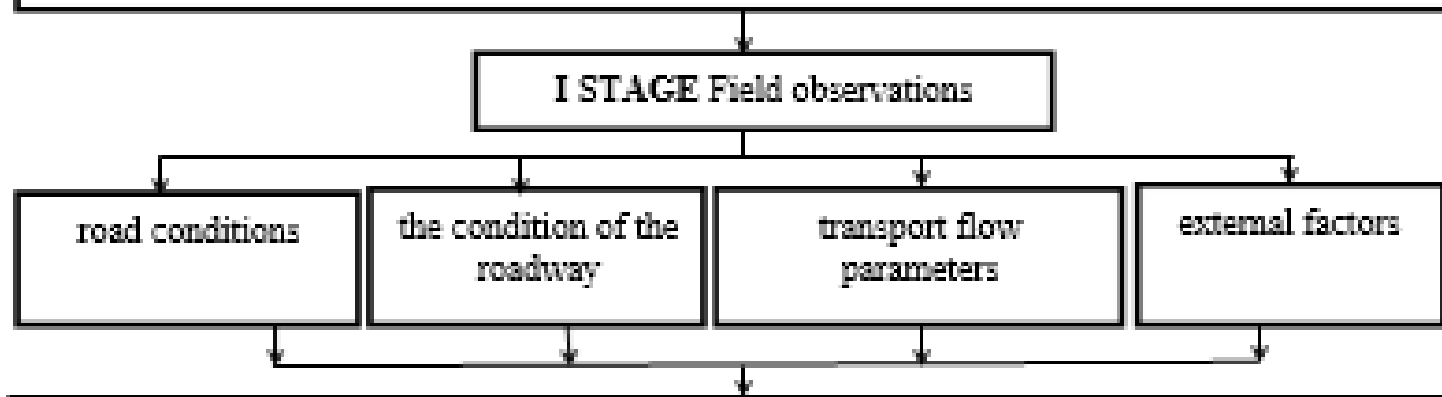

II STAGE Estimation of acoustic pollution of the territory along the highway

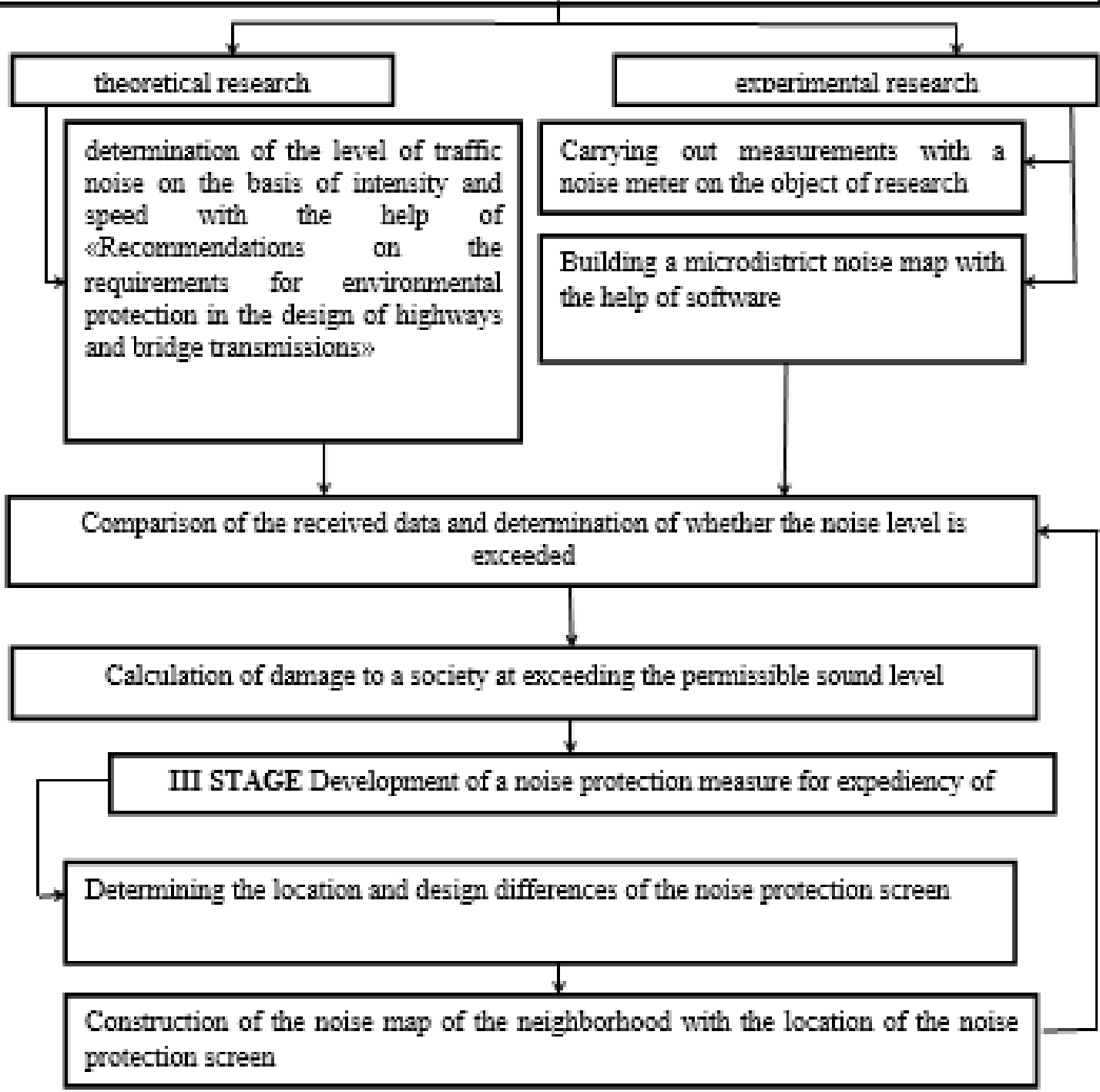

Figure 2. Stages of the research 
ROMANIAN JOURNAL

OF TRANSPORT INFRASTRUCTURE

Elena Lezhneva, Katerina Vakulenko, Andrii Galkin

Assessment of traffic noise pollution due to urban residential road transport

Table 1. Characteristics of the research area

\begin{tabular}{|c|c|c|}
\hline Residential & Indicators & Characteristic \\
\hline \multirow{5}{*}{$\begin{array}{c}\text { Plekhanivska } \\
\text { street }\end{array}$} & approximatelongitudinal slope on the run, $\%$ & 0 \\
\hline & surface & asphalt concrete \\
\hline & number of lanes on the road & 2 \\
\hline & distance to building, $\mathrm{m}$ & $30-150$ \\
\hline & length of the study section, $\mathrm{m}$ & 650 \\
\hline \multirow{5}{*}{$\begin{array}{c}\text { Derzhavinska } \\
\text { street }\end{array}$} & approximatelongitudinal slope on the run, $\%$ & 0 \\
\hline & surface & asphalt concrete \\
\hline & number of lanes on the road & 2 \\
\hline & distance to building, $\mathrm{m}$ & $20-100$ \\
\hline & length of the study section, $m$ & 900 \\
\hline \multirow{5}{*}{$\begin{array}{l}\text { Molochna } \\
\text { street }\end{array}$} & approximatelongitudinal slope on the run, $\%$ & 0 \\
\hline & surface & asphalt concrete \\
\hline & number of lanes on the road & 2 \\
\hline & distance to building, $\mathrm{m}$ & $50-100$ \\
\hline & length of the study section, $\mathrm{m}$ & 540 \\
\hline \multirow{5}{*}{$\begin{array}{l}\text { Haharina } \\
\text { avenue }\end{array}$} & approximatelongitudinal slope on the run, $\%$ & 0 \\
\hline & surface & asphalt concrete \\
\hline & number of lanes on the road & 8 \\
\hline & distance to building, $\mathrm{m}$ & $10-50$ \\
\hline & length of the study section, $m$ & 960 \\
\hline
\end{tabular}

Observations on the intensity of traffic were carried out at different times of day in the morning, day and evening hours of 20 minutes of each time interval on weekdays and weekends, after which the average arithmetic number of passing cars per hour through each observation point was calculated [20]. Separate counting of cars, light trucks, medium trucks, heavy trucks and buses was carried out. In the generalized form, the results of the studies are given in Table. 2

From the analysis of the results of observations, a number of conclusions can be made:

- the main contribution to traffic flows are the individual cars, around $81 \%$. The number of buses in percents is no more than $4 \%$ of the total number of vehicles;

- the intensity of the traffic on the studied areas is approximately the same in the winter and summer periods of the year; 
ROMANIAN JOURNAL

OF TRANSPORT INFRASTRUCTURE

Elena Lezhneva, Katerina Vakulenko, Andrii Galkin

Assessment of traffic noise pollution due to urban residential road transport

- on weekends there is a decrease in the intensity of traffic. In the summer period, the number of cars on Sunday is $51-74 \%$ of their total on weekdays, in the winter $-45-64 \%$.

Table 2. Results of monitoring of the intensity and composition of the traffic flow

\begin{tabular}{|c|c|c|c|c|c|c|c|}
\hline \multirow{2}{*}{ Street name } & \multicolumn{5}{|c|}{ Average traffic intensity, aut./hr } \\
\cline { 2 - 8 } & cars & $\begin{array}{c}\text { light } \\
\text { trucks }\end{array}$ & $\begin{array}{c}\text { mid-size } \\
\text { cargo }\end{array}$ & $\begin{array}{c}\text { heavy } \\
\text { cargo }\end{array}$ & $\begin{array}{c}\text { buses, } \\
\text { trolley buses }\end{array}$ & total \\
\hline $\begin{array}{c}\text { Plekhanivskas } \\
\text { treet }\end{array}$ & $\%$ & 81,4 & 8,6 & 2,2 & 4,4 & 3,6 & 100 \\
\cline { 2 - 8 } & $\begin{array}{c}\text { average } \\
\text { value }\end{array}$ & 1536 & 169 & 43 & 80 & 60 & 1888 \\
\hline \multirow{2}{*}{$\begin{array}{c}\text { Haharina } \\
\text { avenue }\end{array}$} & $\%$ & 81,5 & 4,7 & 3,5 & 4,8 & 5,5 & 100 \\
\cline { 2 - 8 } & $\begin{array}{c}\text { average } \\
\text { value }\end{array}$ & 2546 & 146 & 109 & 154 & 176 & 3124 \\
\hline $\begin{array}{c}\text { Molochna } \\
\text { street }\end{array}$ & $\begin{array}{c}\text { average } \\
\text { value }\end{array}$ & 78,4 & 7,7 & 6,2 & 5,4 & 2,3 & 100 \\
\hline \multirow{2}{*}{$\begin{array}{c}\text { Derzhavinska } \\
\text { street }\end{array}$} & $\begin{array}{c}\text { average } \\
\text { value }\end{array}$ & 1562 & 97 & 78 & 68 & 30 & 1272 \\
\cline { 2 - 8 } & 67,6 & 2,7 & 5,6 & 4,2 & 100 \\
\hline
\end{tabular}

At the second stage of the study, as part of the assessment of acoustic contamination of the territory along the highway and theoretical study, the analysis of calculation methods was carried out and it was found that the most objective noise characteristics of the flow can be determined according to the methodology set forth in the "Recommendations on the requirements for environmental protection in the design of highways and bridge transmissions» [4]. This technique allows to determine the level of sound at a distance of 7,5 $\mathrm{m}$ from the traffic flow with the slightest error (the mean squared deviation is 1-2 dBA). In calculations the average speed of the flow was taken $50 \mathrm{~km} / \mathrm{h}$ as average value at night and weekends, and $35 \mathrm{~km} / \mathrm{h}$ during the day, the correction for the road surface $-1,5 \mathrm{dBA}$. The results of calculations are presented in Table 3.

This is a very important transport artery, about $10 \mathrm{~km}$ long, linking the urban core with the airport. The architectural appearance of the avenue is formed not only by residential multistory buildings and new buildings, but also public buildings, buildings of industrial enterprises, research institutes [21]. 
ROMANIAN JOURNAL

OF TRANSPORT INFRASTRUCTURE

Elena Lezhneva, Katerina Vakulenko, Andrii Galkin

Assessment of traffic noise pollution due to urban residential road transport

Table 3.Noise characteristics of the traffic flow at different residences

\begin{tabular}{|c|c|c|c|c|c|}
\hline \multirow{2}{*}{ Street name } & \multicolumn{2}{|c|}{ Intensity,aut./hr } & \multirow{2}{*}{$\begin{array}{c}\text { Percentage } \\
\text { of }\end{array}$} & \multicolumn{2}{|c|}{$\begin{array}{c}\text { Equivalent sound } \\
\text { level, dBA }\end{array}$} \\
\cline { 2 - 3 } & daytime & $\begin{array}{c}\text { at } \\
\text { nighttime }\end{array}$ & trucks,\% & daytime & $\begin{array}{c}\text { at } \\
\text { nighttime }\end{array}$ \\
\hline Plekhanivskastreet & 1888 & 362 & 18,8 & 77 & 71,5 \\
\hline Haharina avenue & 3124 & 657 & 18,5 & 78,5 & 74,5 \\
\hline Molochna street & 1272 & 195 & 21,6 & 74,5 & 66,5 \\
\hline $\begin{array}{c}\text { Derzhavinska } \\
\text { street }\end{array}$ & 1862 & 344 & 16,1 & 76 & 72 \\
\hline
\end{tabular}

As shown in the data given in Table 3, the noise characteristics of the traffic flow in the local area is 75-79 dBA at the day time and 67-75 dBA at night. The most acoustically loaded area is Haharina avenue (Fig. 3).

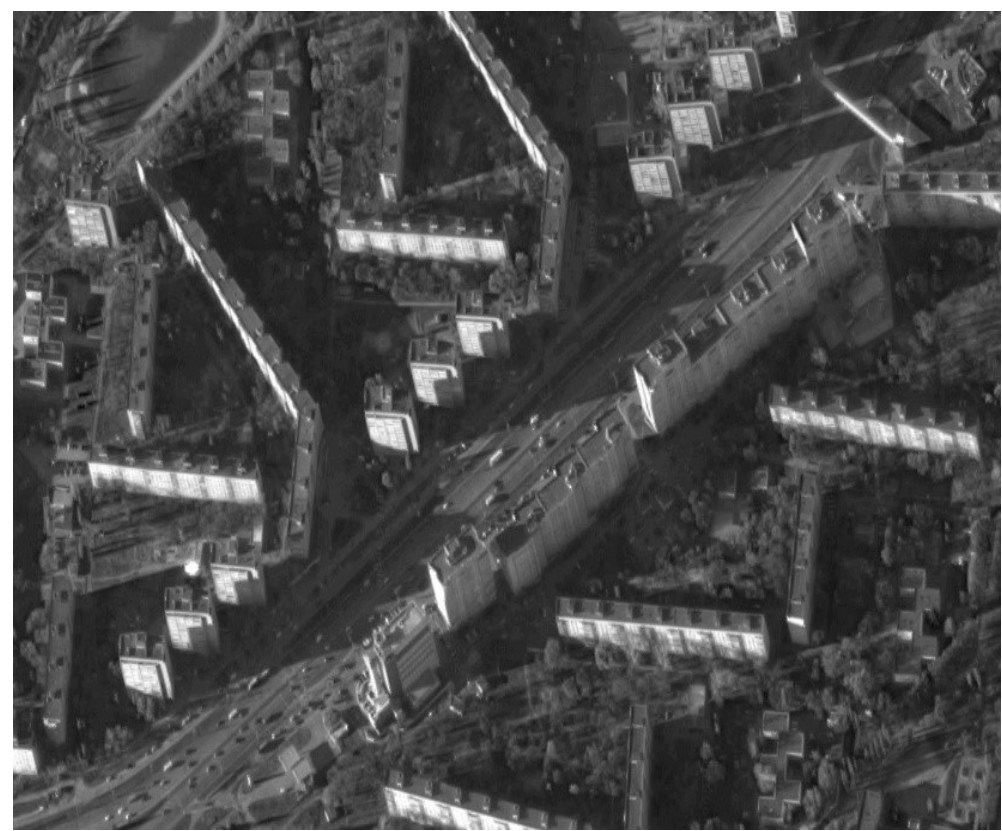

Figure 3. Topview of Haharina avenue area

Experimental research is a prerequisite for ensuring the completeness of scientific research. In the organization of experimental studies of traffic flows it should be noted that they are characterized by the presence of a significant amount of source data with incomplete reliability, as well as the practical inability to conduct the experiment in clean conditions.

The estimation of traffic flow noise was carried out on the basis of the standard [22], which determines that the noise characteristic of traffic flows is 
ROMANIAN JOURNAL

OF TRANSPORT INFRASTRUCTURE

Elena Lezhneva, Katerina Vakulenko, Andrii Galkin

Assessment of traffic noise pollution due to urban residential road transport

an equivalent sound level $L_{\text {Аекв}}$. This standard defines the conditions for conducting noise measurements of traffic flows, namely: the placement of the measurement location at a distance of not less than $50 \mathrm{~m}$ from the intersection, public transport stops in places with a constant speed of movement; absence of moisture or dirt on the surface of investigated roads; the time of measurements must coincide with the maximum traffic flow; the wind speed during the measurement should not exceed $5 \mathrm{~m} / \mathrm{s}$. The measurements were carried out on Haharina avenue (a site between Molochna Street and Derzhavinska Street) at a distance of 7,5 $\mathrm{m}$ from the axis of the lane closest to the point of measurement, at a height of $1,5 \mathrm{~m}$ from the road surface using a DT-8852 class sound meter accuracy 2. In this case, the microphone was not located closer than $1 \mathrm{~m}$ to the wall of buildings or other structures reflecting sound. When measuring, the microphone was oriented towards the traffic flow.

In parallel with the measurements of noise levels of the traffic flow, a video stream of traffic flow was made, which allowed to obtain detailed information regarding its composition. Total duration of measurements is not less than 30 minutes, consisting of three cycles every 10 minutes 3-4 times a day, according to methodology $[20,25]$. A graphical representation of sound level measurement is shown in Fig. 4.

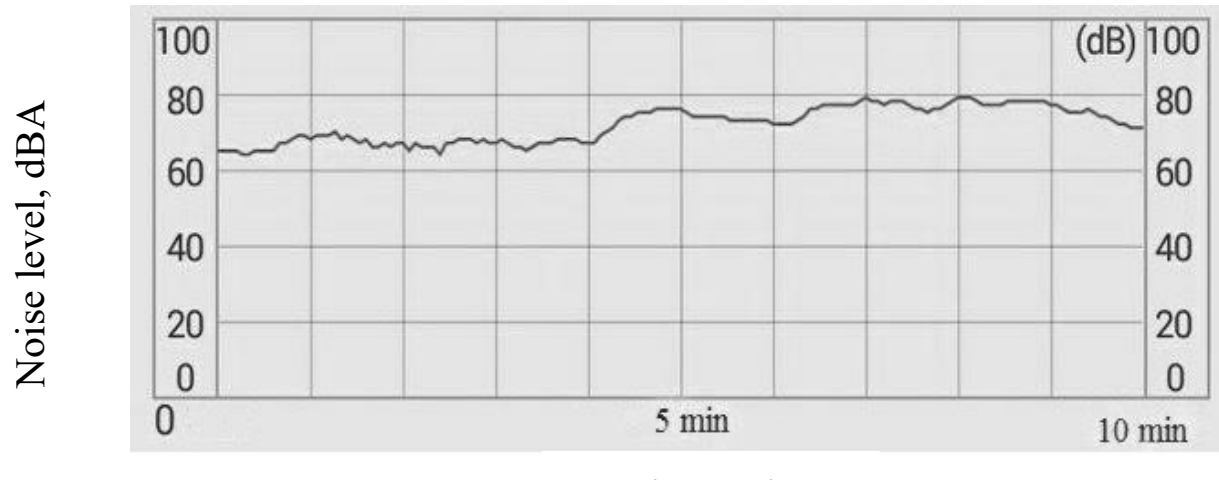

Time, $\min$

Figure 4. Results of measurement of sound pressure level

The processing of experimental data was carried out according to the method [23], which provides the determination of equivalent noise levels based on the number of counts of noise levels by intervals. In Table 4 the results of experimental studies of traffic noise emission on Haharina avenue are presented. 
ROMANIAN JOURNAL

OF TRANSPORT INFRASTRUCTURE

Elena Lezhneva, Katerina Vakulenko, Andrii Galkin

Assessment of traffic noise pollution due to urban residential road transport

Table 4. Results of experimental studies of noise emission of road transport flows

\begin{tabular}{|c|c|c|c|c|c|c|c|c|c|c|}
\hline \multirow[t]{2}{*}{$\begin{array}{l}\text { Street } \\
\text { name }\end{array}$} & \multirow{2}{*}{ 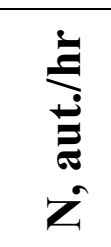 } & \multicolumn{8}{|c|}{$\begin{array}{l}\text { The proportion of the number of counts in a given } \\
\text { range of sound levels, } \mathrm{dBA} \text {, in the total number of } \\
\text { counts, } \%\end{array}$} & \multirow[t]{2}{*}{$\begin{array}{l}L_{\text {Аекв }}, \mathbf{d B A}\end{array}$} \\
\hline & & $48-52$ & $53-57$ & 58-62 & $63-67$ & $68-72$ & 73-77 & $78-82$ & $83-87$ & \\
\hline $\begin{array}{c}\text { Haharina } \\
\text { avenue }\end{array}$ & 3124 & 0,9 & 2,2 & 5,9 & 11,4 & 12,7 & 30,1 & 36,8 & 0 & 80 \\
\hline
\end{tabular}

According to the results of experimental studies, it was found that $L_{\text {Аек }}$ is equal to $80 \mathrm{dBA}$. The results obtained by theoretical and experimental methods coincide.

Due to the fact that the noise map, in comparison with the method of discrete calculations for each selected control/calculation point, allows instantly to know the exact noise levels absolutely at any point throughout the study area; it was decided to assess the level of acoustic loading through the program «Acoustics 3D». For this purpose, the map of the section of the road of Haharina avenue was downloaded to the program, and all objects were further mapped on it. The noise map for the investigated area prior to the implementation of the environmental protection measure is presented in Fig. 5

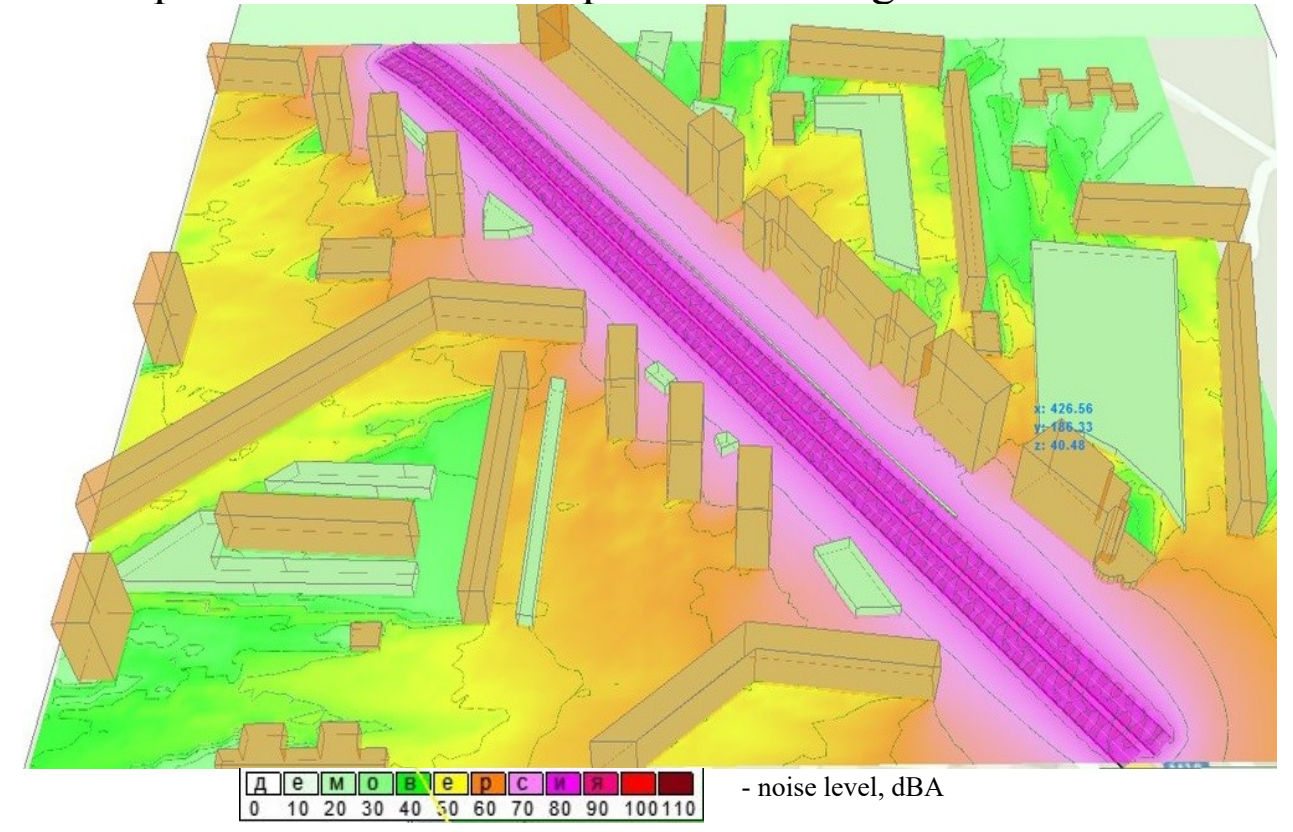

Figure 5. The noise map of Haharina avenuebefore the implementation of the environmental protection measure

The «3D Acoustics»software allows you to assess the level of acoustic stress on the environment[24].The practical result is the noise map of the 
ROMANIAN JOURNAL

OF TRANSPORT INFRASTRUCTURE

Elena Lezhneva, Katerina Vakulenko, Andrii Galkin

Assessment of traffic noise pollution due to urban residential road transport

territory. Noise map is a plan of the limited area with the data on the noise situation, which allows to estimate the complex influence of noise from all sources in the territory, the impact of noise from individual sources, as well as to predict the total noise effects for the territory. The advantage of noise maps is the ease of their perception. The color-coded zones correspond to specific levels of sound, which allows you to estimate the noise levels of any point of the area in the shortest time.

It can be seen from the noise map that the noise level is rather high $L_{\mathrm{A}}$ 70-80 dBA and exceeds the permissible noise level $L_{\text {Аекв, }}$ which is 55-70 dBA. The high noise level is observed in the courtyards of buildings and on the territoryalongthehighway, in the courtyards this indicator falls sharply. The noise map made it possible to estimate the boundaries of the territories where the standard sound level of $55 \mathrm{dBA}$ is reached.These data are presented in the form of isodecibels of different colors.

In the economic assessment of the impact of transport noise, damage from its action was defined as the loss of a part of national income as a result of the constant impact of noise per person [25].The calculation of hourly losses using the coefficient of reducing the national income from the influence of noise was performed by the formula:

$$
3_{h}=C_{h} \sum_{i=1}^{n} N_{L_{i}} \cdot K_{n}\left(L_{i}\right),
$$

where $3_{h}$ - hourly damage from high levels of traffic noise, USD/hr;

$C_{h}$ - cost of one person's work per hour, USD/hr;

$N_{L_{i}}$ - the number of people who are affected by the noise level $L_{i}$, ppl.;

$K_{n}\left(L_{i}\right)$ - the rate of reduction of national income.

Thus, the damage from noise pollution of the environment is about 39 dollars per hour for every 100 people and is directly dependent on the level of noise in the apartments and the number of inhabitants on whom it operates (Table 4).

The estimated level of acoustic load indicates that the noise level is exceeded.

Within the framework of the third stage of the study, it was established that one of the most promising areas of protection of the residential zone and workplaces located in the premises of buildings located near transport routes is the use of acoustic screens[26, 27]. Among the advantages of using acoustic screens in comparison with, for example, greenery should be noted sustainable efficiency, regardless of the period of the year, the density of the leaves. In addition, the effectiveness of the acoustic screens comes from the moment they 
ROMANIAN JOURNAL

OF TRANSPORT INFRASTRUCTURE

Elena Lezhneva, Katerina Vakulenko, Andrii Galkin

Assessment of traffic noise pollution due to urban residential road transport

are installed, while for the achievement of a certain noise protection efficiency green plantations need a long time, until the trees and the bushes will reach a certain height and other characteristics. It is proposed to install a combined noise protection screen, consisting of noise-absorbing and noise-reducing panels, on the left side of the passage of $500 \mathrm{~m}$ length and on the right passage 369 mlength (Fig. 6).

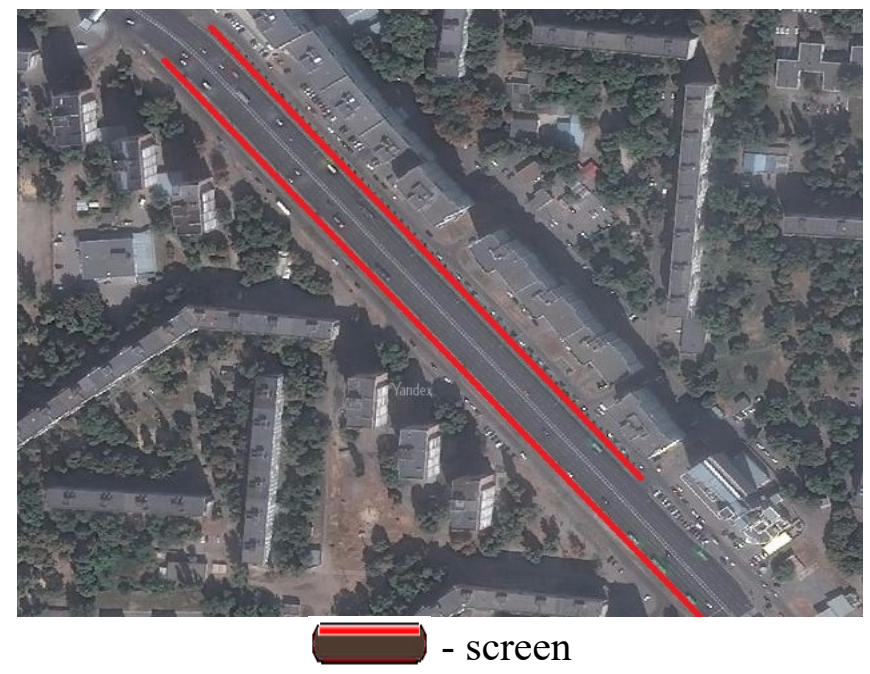

Figure 6. Placement of a combined noise protection screen

Due to the need to ensure visual comfort of the inhabitants of the residential area and sufficient visibility of drivers, the protective engineering constructions should be transparent, but this worsens their protective properties. Therefore, a combined design of a protective screen is proposed, which includes a combination of translucent and sound absorbing modules (Fig. 7).

This design of a protective engineering structure not only allows to effectively protect the area adjacent to the highway from noise traffic pollution, but also allows to maintain a sufficient visibility of the road and does not aggravate the overall view of the street. 
ROMANIAN JOURNAL

OF TRANSPORT INFRASTRUCTURE

Elena Lezhneva, Katerina Vakulenko, Andrii Galkin

Assessment of traffic noise pollution due to urban residential road transport

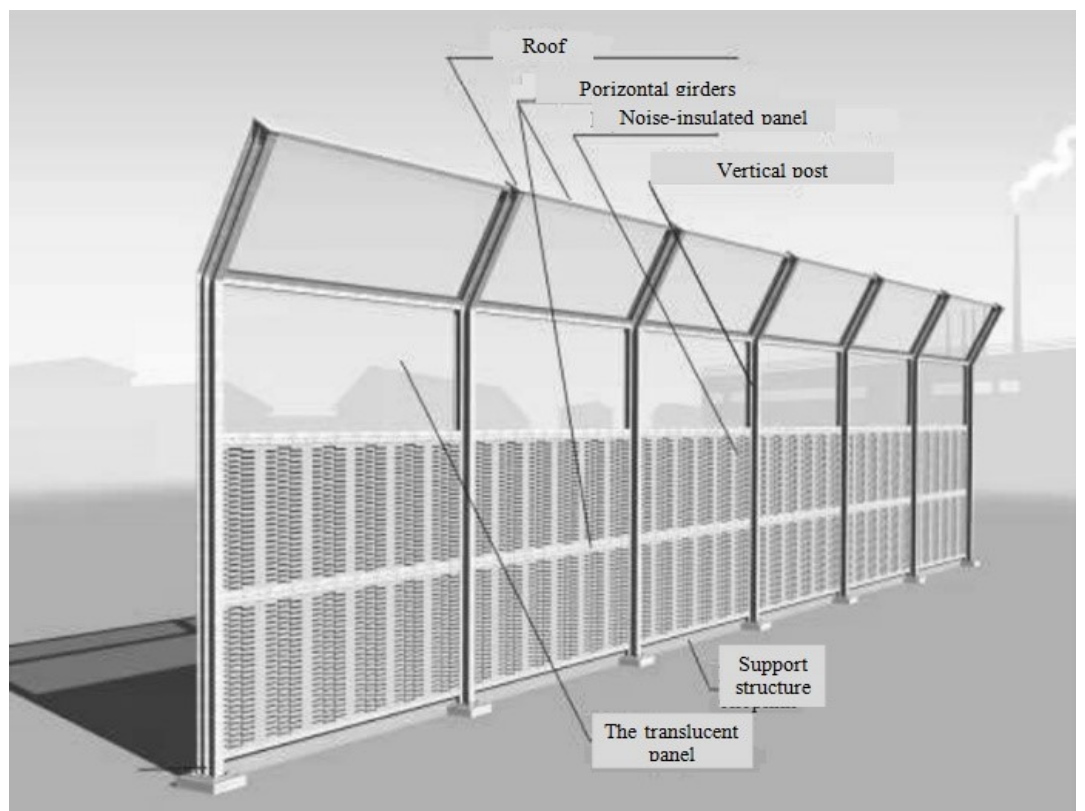

Figure 7.The design of a combined noise protection screen

With the program «Acoustics 3D» a noise map was created for the area under study with the location of the noise-protecting screen (Fig. 8).It is clear from the noise map that the efficiency of reducing the noise load with the use of a combined noise protection screen reaches 8-15 dBA and $L_{\text {Аекв }}=55-65 \mathrm{dBA}$, which does not exceed the permissible noise level.

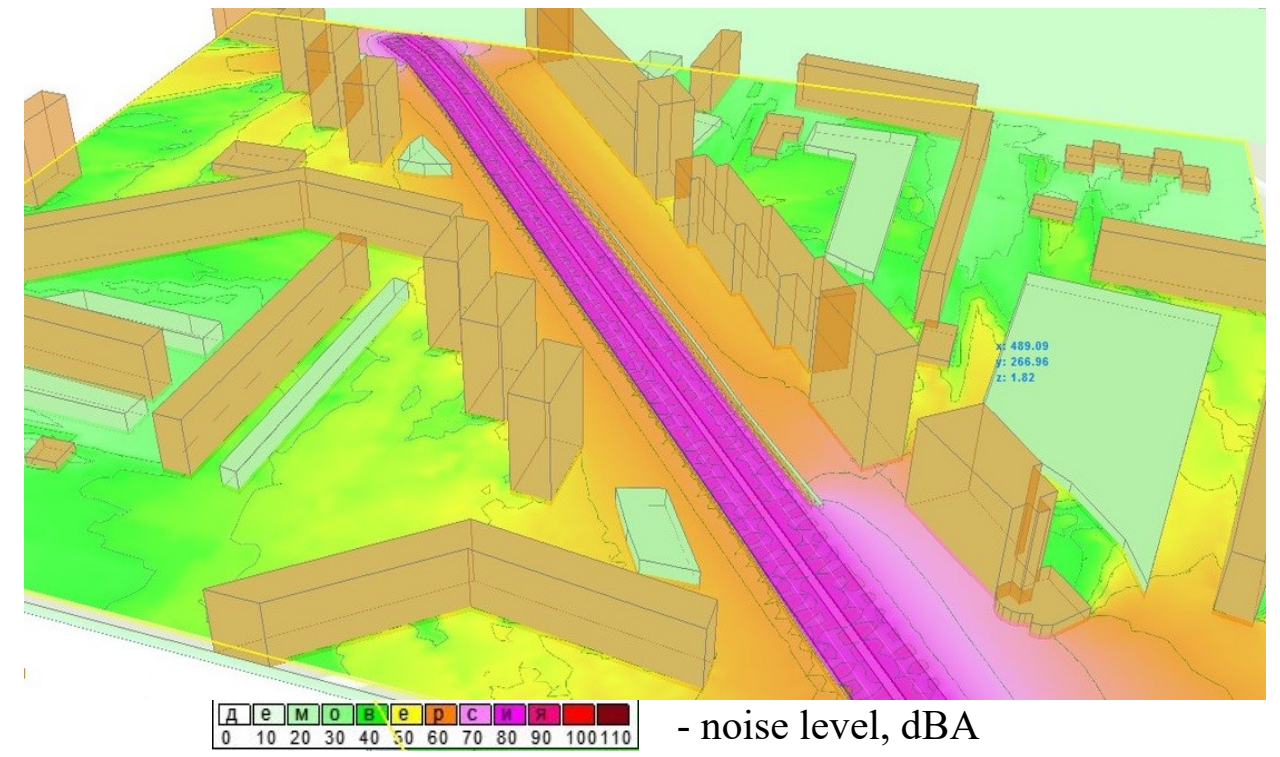

Figure 8. Noise map of Haharina avenue after the implementation of the environmental measure 
ROMANIAN JOURNAL

OF TRANSPORT INFRASTRUCTURE

Elena Lezhneva, Katerina Vakulenko, Andrii Galkin

Assessment of traffic noise pollution due to urban residential road transport

The damage that causes noise exposure with a sound level $=60 \mathrm{dBA}$, provided that its effect on 100 people is about $\$ 15 / \mathrm{h}$. The results of the calculation of eq. 2 are summarized in Table 5.

Table 5. - Results of research and implementation of environmental protection measure

\begin{tabular}{|c|c|c|c|}
\hline Indicators & $\begin{array}{c}\text { Before implementing } \\
\text { the measure }\end{array}$ & $\begin{array}{c}\text { After implementing } \\
\text { the measure }\end{array}$ & $\Delta$ \\
\hline Noise level, dBA & 80 & 60 & -20 \\
\hline $\begin{array}{l}\text { Damage from noise } \\
\text { impact on every 100 } \\
\text { people, USD/hr }\end{array}$ & 39 & 15 & -24 \\
\hline
\end{tabular}

This means that the placement of a noise protection screen in this area of Haharina avenue is an appropriate method for reducing noise. For other streets and sections on them, the necessity of installation panels can be assisting the suggested methodology.

\section{CONCLUSIONS}

In order to estimate the complex influence of noise from all sources and the influence of noise from individual sources, as well as to predict the total noise impact, a map of noise load on the territory along the highway was constructed (before and after the implementation of the environmental protection measure). The maps of noise load on the territory along the highway before and after the implementation of the environmental protection measure were constructed.According to the results of the research, it was found that the residential areas are subject to increased levels of sound. Haharina avenue is in the zone of acoustic discomfort (noise level $80 \mathrm{dBA}$ ), which exceeds the permissible noise level $-70 \mathrm{dBA}$. The results of calculations allow us to estimate the extent of man-caused impact during the operation of the highway on the state of the environment - 39 USD per hour per every 100 people.

As a measure of combat against traffic noise in the territory along the highway, the location of the noise protection screen is justified. It has been established that placing a combined noise protection screen will reduce the noise level by about 8-15 dBA. The results of the studies allow the introduction of administrative and legislative measures to ensure the standard sound levels for residential areas adjacent to highways and to ensure environmental safety in the organization of traffic on the streets of large cities. 
ROMANIAN JOURNAL

OF TRANSPORT INFRASTRUCTURE

Elena Lezhneva, Katerina Vakulenko, Andrii Galkin

Assessment of traffic noise pollution due to urban residential road transport

Studies were conducted for one of the districts of the city of Kharkov, although for other areas you can get other results that depend on:characteristics of the traffic flow, characteristics of the environment, weather-climatic conditions,territory along the highway. Variation the parameters of these characteristics lead to a change in the noise level in a given area.

The feasibility of creating a noise map for the whole city will assess the influence of each of the listed factors on the noise level and thereby form the degree of influence of factors on the noise level. The noise map allows you to find the most problematic and costly places for city dwellers, which allows you to focus the attention of local authorities on solving noise-related priorities. The use of different methods of dealing with noise has a different effect of reducing the noise level for different territories. Creating a benchmark map in terms of noise level will allow reducing the noise level in an urban residential area, it will also help to increase the level of comfort for inhabitants, which will affect the value of real estate in this area.

\section{REFERENCES}

[1]. MURPHY E., KING T.Environmental Noise Pollution, Noise Mapping, Public Health and Policy.University of Hartford, CT, Elsevier Inc.,282, 2014.

[2]. JAMES P. CHAMBERS. Noise Pollution. Advanced Air and Noise Pollution Control, 2, 441-452, 2005.

[3]. BERG, W., BORGMANN, K., HIEMESCH, O., LENZ, H. P., \& PRÜlleR, S. Traffic and environment (Vol. 3). Springer Science \& Business Media,2004.

[4]. PASSCHIER-VERMEER, W., \& PASSCHIER, W. F. Noise exposure and public health. Environmental health perspectives, 108(suppl 1), 123-131, 2000.

[5]. SINGH, N., \& DAVAR, S. C.Noise pollution-sources, effects and control. Journal of Human Ecology, 16(3), 181-187,2004.

[6]. STANSFELD, S. A., \& MATHESON, M. P.Noise pollution: non-auditory effects on health. British medical bulletin, 68(1), 243-257, 2003.

[7]. DULFAN, S. B., \& LOBASHOV O. O. About the influence of intercepting parking on traffic flows in Kharkiv. Technology audit and production reserves, 1(3 (21)), 1922,2015

[8]. BERGLUND, BIRGITTA, THOMAS LINDVALL, AND DIETRICH H. SCHWELA, eds. Guidelines for community noise. World Health Organization, 1995. 
ROMANIAN JOURNAL

OF TRANSPORT INFRASTRUCTURE

Elena Lezhneva, Katerina Vakulenko, Andrii Galkin

Assessment of traffic noise pollution due to urban residential road transport

[9]. BALDAUF, R., THOMA, E., KHLYSTOV, A., ISAKOV, V., BOWKER, G., LONG, T., \& SNOW, R.Impacts of noise barriers on near-road air quality. Atmospheric Environment, 42(32), 7502-7507,2008

[10]. GALKIN, A.; LOBASHOV, O.; CAPAYOVA, S.; HODAKOVA, D.; SCHLOSSER, T.Perspective of decreasing of road traffic pollution in the cities. International Multidisciplinary Scientific GeoConference-SGEM, 4.2 (18), 547-554, 2018DOI: $10.5593 /$ sgem 2018/4.2/S19.071

[11]. CALIXTO, A., DINIZ, F. B., \& ZANNIN, P. H. The statistical modeling of road traffic noise in an urban setting. Cities, 20(1), 23-29, 2003

[12]. KOTZEN, B., \& ENGLISH, C.Environmental noise barriers: a guide to their acoustic and visual design. CRC Press, 2014

[13]. AHAC, S., HALADIN, I., LAKUŠIĆ, S., \& DRAGČEVIĆ, V. Croatian Experience in Road Traffic Noise Management-Concrete Noise Barriers. Romanian Journal of Transport Infrastructure, 3(1), 1-11, 2014.

[14]. LUZZI, S., BALDACCHINI A., BELLOMINI R.. "A standard procedure for acoustic design of railway noise barrier" ICSV12 Proceedings (2005).

[15]. REMMER, D., \& ROCHA, J. Photovoltaic noise barrier-Canada. In SESCI 2005 Conference (pp. 20-24)2005, july

[16]. BECA, I. M., \& ILIESCU, M. The Sunet System for Monitoring Noise Pollution in Cluj-Napoca. Romanian Journal of Transport Infrastructure, 6(2), 33-44, 2017

[17]. GARG, N., SINHA, A. K., DAHIYA, M., GANDHI, V., BHARDWAJ, R. M., \& AKOLKAR, A. B. Evaluation and Analysis of Environmental Noise Pollution in Seven Major Cities of India. Archives of Acoustics, 42(2), 175-188, 2017.

[18]. DEN BOER, L. C., \& SCHROTEN, A. Traffic noise reduction in Europe. CE Delft, 14, 2057-2068, 2007.

[19]. CIHLÁŘOVÁ, D., FENCL, I., CÁPAYOVÁ, S., \& POSPÍŠIL, P.Use of Adhesion Promoters in Asphalt Mixtures, Slovak Journal of Civil Engineering, 26(1), 19-24, 2018. doi: https://doi.org/10.2478/sjce-2018-0003

[20]. BOCHAROV A.A., SOLOVEV A.V. Vliyanie intensivnosti transportnogo potoka na obschiy uroven akusticheskogo zagryazneniya. Izvestiya vuzov. Fizika, 53(9/3), 225226, 2010.

[21]. KAPSKI, D., KASYANIK, V., LOBASHOV, O., VOLYNETS, A., KAPTSEVICH, O., \& GALKIN, A.Estimating the Parameters of Traffic Flows on the Basis of Processing of Localization Data on the Movement of Vehicles, Communications- 


\section{ROMANIAN JOURNAL \\ OF TRANSPORT INFRASTRUCTURE}

Elena Lezhneva, Katerina Vakulenko, Andrii Galkin

Assessment of traffic noise pollution due to urban residential road transport

Scientific letters of the University of Zilina 21(2), 89-99, 2019.

[22]. DIRECTIVE, E. U. (2002). Directive 2002/49/EC of the European parliament and the Council of 25 June 2002 relating to the assessment and management of environmental noise. Official Journal of the European Communities, L, 189(18.07), 2002.

[23]. LUZZI, S., \& VASSILIEV, A. V. A comparison of noise mapping methods in Italian and Russian experiences. In: Forum Acusticum Budapest (pp. 1051-1056), 2005

[24]. www.noiseview.ru

[25]. ŁOWICKI, D., \& PIOTROWSKA, S.Monetary valuation of road noise. Residential property prices as an indicator of the acoustic climate quality. Ecological Indicators, 52, 472-479, 2015

[26]. MIKITIN D.P., NOVIKOV Yu.V. Okruzhayuschaya sreda i chelovek. Moscow: VSh, 1980.

[27]. I.M. BECA: "Contributions on the implementation of complex noise pollution monitoring systems in the context of urban traffic development", Doctoral Thesis, Cluj-Napoca, 2014. 